\title{
The Education Of (Military) Leadership Personnel In A Postmodern World
}

By Edwin R. Micewski ${ }^{*}$

I see many soldiers: if only I could see many warriors!

What they wear is called uniform: may what they conceal with it not be uniform too!

The concepts of education and postmodernism are, most often, neither clearly explored nor unequivocally defined. The two terms are fairly intricate and most controversially debated. They both allow for several different interpretations, tolerating contrasting ways in which to intellectually approach the subject. This essay intends to stimulate reflection and will present some ideas and personal suggestions as to how the military should deal with and join the postmodernist debate.

\section{Some Introductory Philosophical Considerations}

For instance, education can be understood merely as the fulfillment of an occupational qualification or, in full contrast, as a continuous and in itself never-ending process by which a human being forms himself mentally and finds his autonomous realization. One could also comprehend education as the acquisition of knowledge characteristic of a certain culture or society.

Whereas, amidst all this diversity, everyone has his own perception and is aware that education exists, the same cannot be said of postmodernism. "Postmodern" is a very popular term, commonly used in the arts, philosophy, science, and politics. However, while many people use the idiom, nobody really knows what it means, or even stands for, in any way that is meaningful across different contexts or disciplines. And although we attribute the term to key thinkers such as Foucault, Lyotard, and Derrida, and assume that philosophers such as Nietzsche and Heidegger were the originators of the postmodern adventure, the question has been asked with increasing frequency: Is the phenomenon of postmodernism even real?

It might be impossible to describe the phenomenon in all its genealogical history, or to grasp the entirety of the mainly controversial contemporary discourse. There exist a variety of explanatory approaches ranging from:

1. The consideration that postmodernism is merely a part of modernity, to the assumption that it is a true overcoming of modernity.

\footnotetext{
* Brigadier General Dr. Edwin Micewski is Director of the Institute for Military Sociology and Military Pedagogy, Austrian National Defense Academy, Vienna. He has recently completed a secondment to the U.S. Naval Postgraduate School in Monterey.

${ }^{1}$ Friedrich Nietzsche, Thus Spoke Zarathustra (London: Penguin, 1969).
} 
2. The hypothesis that it is just a life-feeling, a sentiment of the spiritual or individual as well as societal orientation to being a noticeable and measurable trend in politics, science, and art; or

3. Postmodernism simply being used as a metaphor, a quasi terminus technicus for the diversity, complexity, and plurality of present-day societies.

An appropriate path to postmodernism may lie in the attempt to carry out a 'negative selection' in the sense of listing those characteristics of modernity this "incomplete project," as Jean-Francois Lyotard has called it - that are questioned and rejected by postmodernism. ${ }^{2}$ The modern world (if we let it start with the Renaissance) cultivated the myth of unlimited and inevitable progress, of freedom as advancing emancipation, and the primacy of nature over religion. The scheme of modernity subscribed to the experimental and quantitative methodology of science, and has acknowledged the supremacy of analytical thinking and universal reason. Hence, in logical consequence, we should necessarily find ourselves in postmodernist thinking when we question the idea of progress, when we rethink the relation between man and nature, when we doubt the omnipotence of rationality and the exclusive efficiency of logical reflection, and when we reject the idea of emancipation in the sense of indifferent equality.

When we consider the "master narratives" of modernity - positivism and Marxism (the latter being the practical-political application of the former) - as gross mistakes, then we might be turning postmodern. When we reject the foremost goal of modernity, namely to bring about the autonomy of the rational human being and the destruction of metaphysics, we might be headed towards postmodernism.

But in all this questioning, doubting, and rejecting we have not found any stable ground or clear orientation. Confusion and uncertainty abound. In the meaning of a profound spiritual and philosophical crisis of our present time, the polymorphous reality of the so-called postmodernist societies has, for quite intelligible reasons, entered into the cultural-philosophical context of decadence.

In his account of five hundred years of Western cultural life, Jacques Barzun extends the etymological meaning of the term decadence as a "falling away." Much more than simple lethargy and paralysis, decadence indicates a lack of purpose and direction, although

implies $[\ldots]$ no loss of energy or talent or moral sense. On the contrary,
it is a very active time. Full of deep concerns, but perfectly restless, for
it sees no clear line of advance. Institutions function painfully.
Repetition and frustration are the intolerable result. Boredom and fatigue
are great historical forces.

${ }^{2}$ See Jean-Francois Lyotard, Das postmoderne Wissen. Passagen (Vienna, 1999).

${ }^{3}$ Jacques Barzun, From Dawn to Decadence: Five Hundred Years of Western Cultural Life (New York: HarperCollins, 2000), xvi. 
If modernity was and is the attempt to divinize reason, then it was and is at the same time the desperation over rationality, together with the anxiety about this partially failed modernist project, that leads to exactly this state of affairs that Barzun describes and that seems to mirror so precisely the present-day condition of Western societies. (Post)modernism celebrates diversity and relativism, and the (post)modern society dissolves into multiple realities, various lifeforms, and different discourses, each with its exclusive ontology and political pragmatics.

There is one element upon which most theories of the postmodern agree: that the mass media play a decisive role in a postmodern society. But, as Gianni Vattimo makes clear, the media (in a media and information society) do not make it more transparent. Even, and perhaps particularly in this respect, a postmodern society is complex and chaotic. The explosion of different views about the world is mirrored in the stupendous dynamic of the media technoculture. Metaphorically, the (post)modern individual is homeless, deprived of a solid foundation by multiple realities, and floating in a seething cauldron of information.

\section{Political and Social Manifestations}

Robert Kagan, in his book Of Paradise and Power, writes of a postmodern and post-historical European paradise. He translates (post)modern decadence into the context of transatlantic power politics and the divide between the U.S. and European strategic cultures. He cites the senior British diplomat Robert Cooper, who stated that Europe today lives in a "postmodern system" that rests on "the rejection of force" and on "self-enforced rules of behavior."4

Cooper is referring to the fact that Europe has neither the will nor the ability to guard its own paradise and keep it from being overthrown, mentally as well as physically. But the Hobbesian world that flourishes outside Europe demands strong commitments. In Kagan's perspective, the United States and some allies who share its views are willing to remain stuck in history and take on the Saddams and Ayatollahs, while leaving others to enjoy the pleasing fruits of their labors.

One inference of Kagan's analysis is that the physical weakness of Europe - in the sense of military incapacity and political disarray - is the cause of Europe's stance on matters of power and security. Although Kagan concludes that the key difference is "less a matter of culture and philosophy than of capability," the exact opposite may be true. It is, perhaps, not economic greed that made most of Europe try to cash in on a peace dividend and neglect their transatlantic commitment after the Cold War was over. Rather, what has to be blamed, by and large, is the strategic culture of Europe as it has been shaped by

\footnotetext{
${ }^{4}$ See Robert Kagan, Of Paradise and Power: America and Europe in the New World Order (New York: Knopf, 2003).
} 
the subtle Cultural Revolution that has unfolded ever since the 1960's, with generations fully captivated by the temptations of modernity. And now, Europe is confronted with the shattered outcome of these fancy dreams, hiding behind the new ideals of a European as well as a global order guided by economic and democratic principles.

The transatlantic divide that has emerged in the wake of the 2003 Iraq War regarding the use of military force, so my assumption goes, has not been a result of incongruent military capabilities, but instead has its basis in the construction and configuration of (post)modern societies. In essence, this constitutes an enormous challenge to Western civilization as a whole.

One of the prominent contemporary American social philosophers, Michael Waltzer, has introduced the notion of unsettlement to describe the social conditions of present-day Western societies. This term comes close to describing the societal features of individual egotism and value relativism - that lack of purpose or direction and the absence of clear courses of progress so astutely described by Barzun.

However, it is not, or at least not only, the pluralism of values that creates the dilemma, but rather what Alasdair MacIntyre has designated as "Emotivism." This term refers to the phenomenon that judgments made by people are only expressions of feelings and personal preferences, and no longer carry any morally essential evidence. No matter what one believes in or stands for, it is equally valid to any other point of view. What this means for the (post)modern liberal nation-state that still has to make vital decisions, not the least in the sphere of foreign affairs and security, can be easily imagined.

It appears that our point of the postmodern critique of modernity is actually the reality of Western-type societies: they have lost their environment of traditional morality and guiding orientation. On the micro-level, it is because of individual aimlessness and relativism. On the macro-level, it is due to the fact that value-generating institutions like churches and other educational authorities are losing their influence.

\section{Effects on the Military}

Granting that soldierly professionalism has to persist in the three-dimensional context of society, politics, and the military, the impact of both the mental and techno-physical realities of such a (post)modern environment will have decisive consequences for matters of security and defense. These consequences will be felt on the functional level in the tasks and missions assigned to the armed forces, and on a societal level in terms of the military's social integration, as well as the overall legitimacy and acceptance the military might enjoy within the political system to which it belongs.

If we agree, with Wittgenstein and Lyotard, that the language game the military system produces - like every other professional entity - not only gen- 
erates a semantic significance but also develops its own patterns of action and organizational culture - its own life-forms, as it were - then the following question comes to the forefront: how should the military system as a whole, and at the level of the individual member, interrelate with this environment?

What are the conditions, requirements, and necessities - but also the limits - for a civil-military and a politico-military discourse and interaction in this setting? Can the military world even sustain its distinct profile without being estranged and excluded from these surroundings, perhaps at the cost of alienation to the extent of being accepted as a necessary evil, an anachronism of times long past? Or will the military be absorbed by this social climate of (post)modern disposition?

With the paradigmatic shift of the global security environment, Western military organizations have developed from primary instruments of national defense into mechanisms of international crisis prevention and conflict resolution. The significantly altered tasks and missions assigned to the armed forces in an internationalized security arena have demanded close civil-military cooperation and, as a result of the changed character of military missions, also an extended horizon for efficient military leadership. While some commentators detect a questionable civilianization of the military, these developments have undoubtedly produced an augmented inclusion of "civil" subjects in the curricula of professional military education.

Does this mean that the civilianization of the military holds the solution? Can the soldier even wish to become absorbed by a society that structures itself as described above? Or rather, to the contrary, is there perhaps the chance for the military to play a role in enriching a society consumed by value arbitrariness, relativism, and skeptical fragmentation by reaching beyond the borders of professional military education?

\section{Educating Leadership Personnel}

While modernity was focused on knowledge, a postmodern approach focuses on wisdom. As the German philosopher Robert Spaemann makes clear, wise is what is prudent not only at first sight. Wisdom has to do with considering all consequences of decisions and acts. Every understanding of education and pedagogy aiming at major impacts, in the sense that at the end of the educational process there stands an exactly described capacity, misses the essence of education when it results in the creation of marionettes and curricular schemes. Only a holistic approach in education enables the student to adapt the content and transform it innovatively as demanded by the situation at hand.

Over time, the philosophical and scientific principles of modernity have reduced education to the status of mere "management of knowledge." Along the lines of analytical reason and linear progress in history, the educational approach was mostly understood as the accumulation of facts and data, 
and more recently, their ready access (if possible, online and easily recallable from a network). No longer was the quality and emancipation of the individual of primary concern, but rather his regulation, aiming at teleological handiness and functionalism. The reductionist tendencies of technical determinism made us lose sight of the essential nature of ourselves as human beings. The consequences of this purely instrumental and teleological understanding of education turned out to be problematic, as a generally poorly oriented and insufficiently self-reliant human was being produced.

This is why, in the wake of postmodern currents, we have recently observed the turn to a concept of education which keeps an eye on the idea of a harmoniously cultured human as well as on the ideal of a comprehensively enlightened person. In this understanding, education embraces the dimensions of knowledge, capabilities, and virtues. Only when it also encompasses the realm of basic morality does it enable everybody to mold himself intellectually and, based on autonomy and self-determination, accomplish the total realization of his human Self. Thus, education is transformed into something that grants any human individual knowledge and wisdom built upon the grand traditions of human effort in the fields of humanities and culture. This qualifies one to build character while, at the same time, bestowing the moment of freedom upon him.

In short, education is more than imparting the immediate knowledge and capacity one might need to carry out his occupational tasks. Education embraces all that unconfined, freely available knowledge that transcends occupational necessities. In a way, the former sets in where the latter ends. Thus, education finally results in a state in which the individual is factually and, in the deepest sense of the word, ethically able to take on "responsibility" Thereby the concept of education is raised up to the level of a cultural task, if not duty, of ethical dimension, a claim that calls upon the individual as fully as any political system.

For military science, Carl von Clausewitz still represents the strong antithesis to modernist positivism and relativism. When he spoke about the "art of war" (Kriegskunst), he was referring to the fact that military leadership is an imaginative rather than a scientific capacity. This is why theory should be contemplation (Betrachtung) rather than dogmatic doctrine, and should lead to "generating ability."

Clausewitz also made clear that theory becomes infinitely more difficult as soon as it touches the realm of "moral values" (geistige Größe). Although the original phrase represents a much broader concept, the underlying idea is that, when it comes to dealing with human life and activity, theory is no longer about predicting and controlling the behavior of things.

Naturally, Clausewitz could not say anything about digital decisionmaking and the gradually disappearing difference between humans and technology. He could not predict the information age, with its information revolution, and the ensuing Revolution in Military Affairs. However, the opposition of 
human and technological paradigms of our day parallels the dilemma between the Clausewitzean model and the positivist approach of the past two hundred years. Since war, in whatever form and on whatever level of technology, will remain a social act, we should never lose sight of the "eternal human face of warfare."

Perhaps the biggest challenge for the contemporary and future education of leaders will be to strike the right balance between "human factors" and technology. "Humanness," in the sense of an intricate mix of physiological, psychological, and sociological factors, will always be more powerful and decisive than any kind of technology. Technology will never be a substitute for creativity, morale, cohesion, esprit, or commitment - forever the supreme factors in winning or losing wars.

\section{Conclusion}

With regard to the postmodernism debate, the West is in transition. The current state of affairs is the period between the breaking apart of modernity and a postmodern future that has yet to fully arrive. In other words, if what we are designating as postmodernism is in reality the falling apart of modernist societies, bringing about this profound heterogeneity in the wake of the disappearance of great ideologies, there may be hope that meaning and direction will be found in this upcoming age of postmodernism. In this case, postmodernism does not necessarily have to represent a continuation of modernism or its further entrenchment, but could rather become a transgression of it that will lead us ahead of the limiting modern dictate of positivist reason.

Hope arises that we will be able to regain the full array of human faculties and forms of knowledge that lie far beyond the confinements of analytical reason. Politically speaking, there must be an expectation and determination to overcome the paralyzing decadence besetting the West.

Given the violent and war-prone condition of most of the post-Cold War world outside the West, and the nature of the threats inside, evolving around economic and social problems, ethnic hostilities and border disputes, illegal migration, organized crime and corruption - all of which can only be resolved through close civil-military cooperation - the discourse within the strategic community will be about competing interests, contending for resources, and a permanent struggle for the legitimacy of claims and demands.

Nevertheless, in an ever more complex arena of security, if the military establishments seize upon this opportunity rightly, the military will undoubtedly be part of the struggle for the spiritual formation of the future. 
THE QUARTERLY JOURNAL

\section{Bibliography}

Barzun, Jacques. From Dawn to Decadence: Five Hundred Years of Western Cultural Life. New York: HarperCollins, 2000.

Kagan, Robert. Of Paradise and Power: America and Europe in the New World Order. New York: Knopf, 2003.

Lyotard, Jean-Francois. Das postmoderne Wissen. Passagen., 1999.

Nietzsche, Friedrich. Thus Spoke Zarathustra. London: Penguin, 1969. 